DOI: https://doi.org/10.47405/mjssh.v6i5.797

\begin{tabular}{|c|c|}
\hline 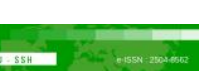 & Malaysian Journal of Social Sciences and Humanities (MJSSH) \\
\hline $\begin{array}{l}\text { Malaysian Journal of } \\
\text { Solabi sciences and }\end{array}$ & Volume 6, Issue 5, May 2021 \\
\hline (mu-ssh) & e-ISSN : 2504-8562 \\
\hline & $\begin{array}{l}\text { Journal home page: } \\
\text { www.msocialsciences.com }\end{array}$ \\
\hline
\end{tabular}

\title{
English Teaching Amidst the COVID-19 Pandemic: Teacher Issues and Challenges
}

\author{
Bernadine Permai Steven Clement' ${ }^{1}$, Melor Md. Yunus ${ }^{1}$ \\ ${ }^{1}$ Faculty of Education, Universiti Kebangsaan Malaysia (UKM)
}

Correspondence: Bernadine Permai Steven Clement (msbelleresearch@gmail.com)

\begin{abstract}
The COVID-19 pandemic affected the globe and every strata of community. Effects can be seen in almost all sectors, education being one of the sectors which was greatly impacted. UNICEF cited a number of 1.6 billion children of schooling age affected by the pandemic. Countries all over the world including Malaysia started working on alternatives to ensure that the learning of schooling children continues throughout the COVID-19 pandemic. The approach chosen by the Malaysian Ministry of Education was to disseminate classes and lessons via online platforms otherwise known as the practice of e-learning. With existing issues of access and gaps in achievement between the rural and urban communities it was a point of interest to investigate how teachers in different contexts dealt with the elearning initiative. In this study, the aim was to measure the attitude of the teacher, their level of technological literacy and the challenges that they face despite of their context. The study was conducted as an online survey involving all the English Teachers in the Limbang district with the total population of English teachers amounting to 103. The return rate of the survey generated 50 responses and the gaps in the research were bridged with a protocoled focus group discussion with 5 teachers. This study echoed the findings of previous studies and highlights pertinent issues which must be dealt with before e-learning can be a strong and viable alternative learning mode for Malaysians.
\end{abstract}

Keywords: COVID-19, English teachers, Malaysian English, e-learning; alternative learning mode

\section{Introduction}

The Online Learning consortium defined e-learning as learning where the delivery of content is done almost entirely (80-100\%) via the internet (Charmonman, 2006). In Malaysia, aspirations to engage the people actively in innovative ways of learning can be seen as early as the 1970s through the setting up of the Educational Technology Division by the Malaysian Ministry of Education in 1972 (Goi \& Ng, 2009). Despite the initiative to bring forward the education system in Malaysia, as a developing country Malaysia still struggles with overcoming the issue of illiteracy among the people. In a projection by the UN, the literacy rate of Malaysia in the year 2020 is $94.85 \%$ which puts Malaysia behind other developing countries such as Mexico, Colombia, and Lebanon (United Nations, 2020).

With the occurrence of COVID-19 and the halt of operations for most sectors, some 1.6 billion children of schooling age have experienced a disruption in their education (UNICEF, 2020). To cope with this and to ensure continuity of learning most educational sectors have turned towards e-learning. In Malaysia, the move towards e-learning have had a continued struggle due to pertinent issues; namely the socioeconomic and digital gap that remains to play a huge factor in the feasibility of e-learning in Malaysia (Kamal, 2020). A circular letter released by the Malaysian Ministry of Education on the 27th 
of March 2020 called upon teachers to continue the teaching and learning process with a strong suggestion to use e- learning mediums (Malaysian Ministry of Education, 2020). Throughout the Movement Control Order, various initiatives have been carried out to increase student's access to elearning in the form of teacher training and also providence of 1GB internet data per day (Yeoh, 2020).

Within the Malaysian community, it is a widely known fact that Sarawak does not have the best educational facilities. Quoting a total number of 1020 dilapidated schools in December 2019 (Borneo Post, 2019), these figures reflect the realities faced by the Limbang teaching community. The teaching community in Limbang face the realities of less-than-ideal facilities and limited access which have caused certain effects on the implementation of the e-learning initiative. This will be discussed further in the findings of the article.

To frame the context of this research, the work of Forero et.al (2019) is referred to. According to Forero et.al, the findings of a research is limited the locality of the context in which it was carried out in. Therefore, the findings of this research can only truly reflect the implementation of the e-learning initiative of the community in Limbang and is not to be generalized into other contexts.

For this research, the participants involved are English teachers teaching in Limbang. Therefore, the findings can only be used to accurately represent the e-learning situation to teach English in Limbang. Secondly, the experiences of the participants are unique to them due to their context. Different teachers experience the implementation of e-learning in their own unique way due to factors such as their familiarity with conducting e-learning activities, the demographic background of their school community as well as their own technological literacy. Lastly, limitations in terms of the instruments. The instrument used in this study measures specific constructs which were key in answering the research questions set for this particular research. The results of this study cannot be used as a reference for an e-learning research which seeks to measure a different set of constructs.

The purpose of this study is to explore the perceptions of English teachers in Limbang on the elearning that they have conducted during the MCO. The study will measure the constructs of the teacher's attitude towards e-learning, their technological literacy, and the challenges the teachers face in facilitating e-learning for their students.

The objectives of the research are as follows:

i. To identify teachers' perceptions on e-learning during MCO.

ii. To identify teachers' technological literacy level.

iii. To identify challenges faced by teachers in implementing e-learning during MCO.

\section{Literature Review}

The main reference for the underlining theories of this survey was adopted from the Anderson model (Anderson, 2011). The Anderson model is chosen as the main reference for this research because in the process of designing the online learning model, Anderson omitted elements of traditional teaching and learning and focused on the three theories which drove the existence of online learning. These are the theories of; community of inquiry (COL), connectivism and online collaborative learning (OCL).

\section{Community of Inquiry (COL)}

Garrison, Anderson \& Archer (2000) introduced the idea of "community of inquiry" as a model for online learning environments. In this school of thought, the internet is seen as an environment where learners can interact and build upon their knowledge by sharing within the community. The founders of the model believed in "presences" which they believed to be antecedents of successful e- learning. The three "presences" named are cognitive, social and teaching. Garrison, Anderson \& Archer's model are made for blended learning as they believe that "presence" will arise through the interactions between the instructor and the learners. Their model has been the base of reference for many discussion boards 
and video-conferencing platforms which are used in education such as Linoit and Padlet (Picciano, 2017).

\section{Connectivism}

MOOC otherwise known as "Massive Open Online Course" which is a widely used platform for online pioneered by George Siemens-the proponent of the connectivism theory. When connectivism was introduced to the academic world, it was revolutionary, and it catalysed many shifts in the way that we understood how knowledge and information flowed. The existence of the World Wide Web has caused bulks of data to travel across vast communication networks. The technology of the internet changed the learning experience from something that was personal into a communal activity from which the members share their knowledge and learned from each other (Picciano, 2017). Siemens quoted Barabasi as well as Stephensen in his article "What Knowledge Tears apart, Networks make whole" which fueled his study on connectivism and accurately identified how large-scale networks became an indispensable tool in helping people learn and manage data and information. To simplify the notion of connectivism, Siemens described it as a theory that is driven by the dynamic flow of information.

Figure 1: The Anderson Model

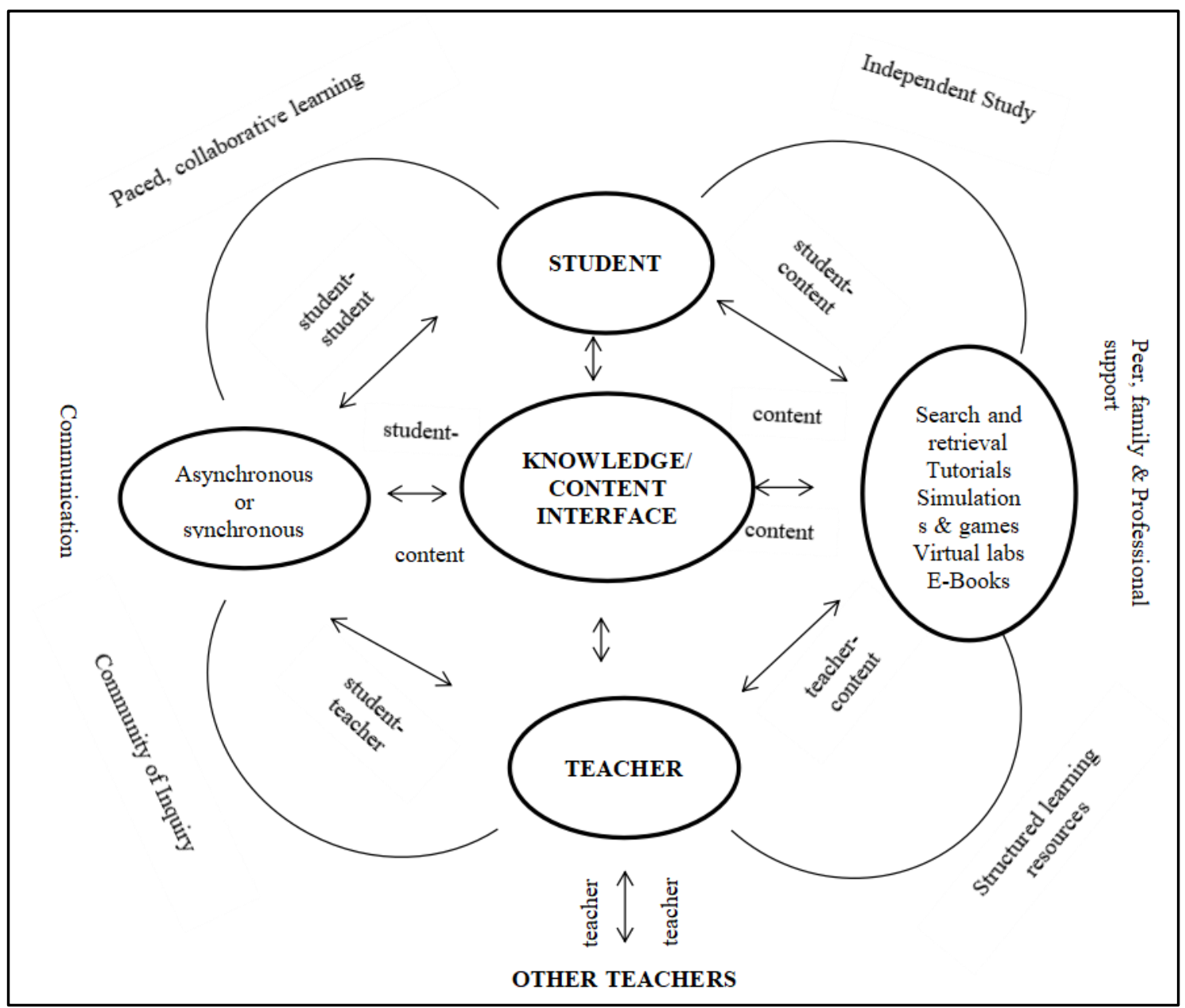

\section{Online Collaborative Learning (OCL)}

Linda Harashim is the proponent of the Online Collaborative Learning (OCL) theory. She believed that OCL is able to explain the process of e-learning where collaboration happens to build upon knowledge. She believes that online learning will reshape all types of education signifying the era of the "Knowledge Age" (Harashim, 2012). Similar to Connectivism, OCL believes in the benefits of moving education to the internet where there is greater access to large communities in which collaborative 
learning can happen. Harashim (2012) draws out three phases in which learning construction happens through a group discourse.

These three phases are:

i. Idea Generating

ii. Idea Organizing

iii. Intellectual Convergence

Hashim also derived ideas from social constructivism as learners are expected to collaborate in problem solving activities in OCL. There are also textbook elements such as the role of the teacher as a facilitator cum learning community member. This groups the OCL together with other constructivist theories where the teacher plays the role as an active facilitator in the knowledge building process.

\section{Methodology}

The research design used for this study is a mixed method approach. The study collects quantitative data in the form of scores from the Likert scale items in the survey and qualitative data from the openended items as well as the discussion of the focus group. A mixed method approach is chosen for this study because it suits the area of research, which is education, a branch in the social sciences (Heyvaert, Hannes \& Onghena, 2017). Data collected from mixed method research have been described to have a more "synergistic utilization" compared to solely exclusive quantitative or qualitative type research (Wisdom \& Creswell, 2013). This contributed to the choosing of this research method as we are looking for a holistic view of a current practice in education and we wanted our data source to be able to link sporadic pieces of information and create a picture of the realities of the situation which is the closest to reality.

\section{Respondents}

The respondents of this research are English teachers who are serving under the Limbang Education District Office. The target number of respondents are at 80 and above due to the total population of English teachers serving in Limbang numbering at 103. This is in accordance with the Krejcie \& Morgan table (1970) to determine the set number of samples for a certain population. With 80 participants the confidence level for the data collected in this research is $95 \%$ with a $5 \%$ margin of error. Respondents are selected via random stratified sampling. In which random English teachers are chosen with the strata of them being English teachers serving in Limbang, having access to the online survey questionnaire during the period of data collection and are willing to partake as a respondent in the research. For the purpose of this study, the teachers involved are both from primary and secondary schools. Since Limbang does not have any private schools, all of the teachers involved are National School teachers.

\section{Survey Questionnaire}

The survey questionnaire item starts with three basic questions to establish the respondent's sex, experience in teaching and school demographic. These are all independent variables which may be analyzed in later stages of the study to discover if any of the attributes plays a factor to the respondent's perceptions towards the effectiveness of e-learning.

The questionnaire then follows up with an introductory question on e-learning which is intended to establish the respondent's familiarity with e-learning. The aim to gauge the respondent's familiarity with e-learning and conducting learning activities via e-learning platforms is divided among several items. As suggested by Price et al. (2017), close-ended items are used to achieve this aim, the item requires the respondents to tick and mention the many e-learning platforms they have tried in a lesson before.

The next section involves the respondents to assess the level that e-learning is being implemented in their school. Respondents are asked to choose which statement reflects the conditions of implementing 
e-learning in the context of their school. These statements were differentiated by the level of effectiveness e-learning is being implemented and the number of issues that arise with the implementation of e-learning during the period of the Malaysian Movement Control Order. Respondents who say that the implementation of e-learning is less effective or not feasible due to issues that arise were asked to identify the issues from a list provided. The respondents are expected to tick all the issues that apply to their context. Space for a short response is also provided should they experience other issues which were not listed on the list provided.

Next in the questionnaire, the respondents are required to rate 1 to 5 on a Likert scale how much a statement applies to them. There are 8 statements in total which the respondents must respond to. The statements comments on the technological literacy of the teachers and their attitude on the e- learning initiative during the Malaysian Movement Control Order. Based on their responses on this section, it will give a glimpse into their level of technological literacy and their attitude or perception on the elearning initiative which are the constructs aimed to be measured in this section (Schwarz, 2015; Price et al. 2017).

In the final section of the questionnaire, the respondents are asked to identify which of the items on the list served as a challenge in their efforts to implement e-learning during the Malaysian Movement Control Order. Respondents are asked to tick all that apply. As before, a space is provided for the respondents to include challenges they face which are not listed in the list. Lastly, in a final effort to tie all the responses together, the respondents were asked to express their feelings towards e- learning both in general and as an alternative way of learning during the Malaysian Movement Control Order. As explained by Schwarz, it is hoped that the attitudes of the respondents towards e-learning are reflected in their words if still unclear by their responses in the close-ended items (2015).

\section{Results and Discussion}

\section{Teacher's Perceptions On E-Learning During MCO}

This construct measures teacher's attitudes which are generalized into 3 categories: positive, neutral, and negative. It concerns the perception of teachers and their attitude towards e-learning during the MCO. The data relating to this are collected from the survey questionnaire and focus group discussion. There are 5 items which measured the construct of attitude from a quantitative standpoint in the survey. The results from the respondents on these 5 items are as follows.

Table 1: Initial Reactions on E-learning

\begin{tabular}{lll}
\hline Response in Survey Item & Frequency & Percent \\
\hline Positive Initial Reception & 28 & $56.0 \%$ \\
Negative Initial Reception & 22 & $44.0 \%$ \\
Total $(\mathrm{N}=50)$ & 50 & $100.0 \%$ \\
\hline
\end{tabular}

Table 1 shows the findings for Attitude Item 12 which measures the attitude of teachers based on their initial reaction on the e-learning initiative. The results show that respondents are divided into two stances, one where they have had experience with conducting e-learning and are therefore confident in conducting e-learning during MCO and the other where they have had no experience in conducting elearning and they are more reserved in their acceptance of the approach. $56 \%$ or 28 out of the 50 respondents claimed that they have had some experience in conducting e-learning therefore they were optimistic about the implementation. The other $44 \%$ or 22 respondents have not had any prior experience in conducting e-learning and therefore are not as optimistic about the implementation.

This item was on initial reception which meant that the respondents could have changed their mind after implementing e-learning during the MCO. Since e-learning done in school had face-to-face interaction 
to supplement and support the process (Mohd Zulhilmi \& Radzuwan, 2019) it is undoubtedly different from e-learning that is done during MCO where the teacher could not have face-to-face interactions with the students.

Table 2: Teacher Perception on Issues

\begin{tabular}{lccc}
\hline \multicolumn{1}{c}{ Response in Survey Item } & Construct & Frequency & Percent \\
\hline There are minor issues & Positive Attitude & 13 & $26.0 \%$ \\
Thinks there are major issues & Neutral Attitude & 32 & $64.0 \%$ \\
Thinks it is feasible & Negative Attitude & 5 & $10.0 \%$ \\
$\quad$ Total $(\mathrm{N}=50)$ & & 50 & $100.0 \%$ \\
\hline
\end{tabular}

Table 2 shows the findings for Attitude Item 2 which measures the constructs of attitude of teachers based on how they feel about issues that arose during their implementation of e-learning. If the teacher felt like there were more issues, they are considered pessimistic about the approach ergo, categorised under the "Negative Attitude" category and the less issues they deem to have arisen, these group of teachers are considered optimistic and falls under the "Positive Attitude" category. In the findings from this item, it was found that $26 \%$ or 13 out of 50 of the respondents have a positive attitude towards the e-learning that happened in their context whereas $64 \%$ or 32 out of 50 of the respondents had a neutral attitude and the other $10 \%$ or 5 out of 50 of the respondents had a negative attitude about the e-learning that happened in their context during the MCO.

When the data is triangulated with data from the open-ended item as well as the focus group discussion, it was found that the "major issues" quoted in the survey refers to the fact that there is delay in relaying information therefore there are not a lot that can be taught in an e-learning session. This delay is caused by the scarcity of resources from the student's side. Older students are prioritized therefore younger students only gain access to e-learning tools such as laptop, computer, mobile phones and tablets after the older siblings are done with their online classes and schoolwork.

One of the participants in the focus group discussion explained the difficulty of carrying out e-learning with financially struggling families saying "there is internet problem, and they are having only one phone but somehow having three or four brothers in school. So that is the problem, they need to share the same phone" (FGD171020).

These occurrences also cause a delay in doing the learning activity as well as a delay in the process of asking questions to the teacher and waiting for the explanation. The issue of delay also exists due to logistical issues as both teachers and students are sometimes bound by the fact that where they live do not have internet access or network coverage as can be seen from an excerpt of the focused group discussion "...even me myself I don't have connection to the internet...sometimes I have to go out like every two weeks because you can't go out every day to check your Whatsapp. So the interval is two weeks time" (FGD171020). This means that information can only be sent out to the students when the teacher travels to the city to get rations.

Table 3: Teacher's Enjoyment in Using Technology

\begin{tabular}{llll}
\hline Response in Survey Item & Construct & Frequency & Percent \\
\hline $\begin{array}{l}\text { I do not enjoy learning how to use } \\
\text { new technology. }\end{array}$ & Negative Attitude & 1 & $2.0 \%$ \\
$\begin{array}{l}\text { I somewhat do not enjoy learning } \\
\text { how to use new technology. }\end{array}$ & Neutral Attitude & 1 & $2.0 \%$ \\
$\begin{array}{l}\text { I am unsure of how I feel about } \\
\text { learning how to use new technology. }\end{array}$ & Neutral Attitude & 4 & $8.0 \%$ \\
$\begin{array}{l}\text { I somewhat enjoy learning how to Positive Attitude } \\
\text { use new technology. }\end{array}$ & 18 & $36.0 \%$ \\
\hline
\end{tabular}



DOI: https://doi.org/10.47405/mjssh.v6i5.797

\begin{tabular}{lccc}
\hline $\begin{array}{l}\text { I enjoy learning how to use new } \\
\text { technology. }\end{array}$ & Positive Attitude & 26 & $52.0 \%$ \\
Total $(\mathrm{N}=50)$ & & 50 & 100.0 \\
\hline
\end{tabular}

Table 3 shows the findings for Attitude Item 3 which measures the attitude of teachers in the context of the enjoyment they experience in using technology. These results show that the majority of the respondents show a positive attitude towards technology with $52 \%$ or 26 out of 50 respondents agreeing with the statement of "I enjoy learning how to use new technology" and another $36 \%$ or 18 out of 50 respondents agreeing with the statement "I somewhat enjoy learning how to use new technology". This is again backed up by the findings in the focus group discussion where the participants talked about exploring new platforms with their students. Most also have a positive attitude on adopting the platforms and merging them into the class activity. Teachers were creative in their use of Whatsapp seeing that it was the most accessible platform to all the students. Even on instances able to conduct writing competitions via Whatsapp as seen from the excerpt:

\begin{abstract}
“...I gave them a simple question using Whatsapp. Okay? Whatsapp. So happens during MCO is this, Mother's Day and then Teacher's Day so, I, to improve their learning, their writing during MCO so their learning is not stopped-still learning, so I carried on this competition, writing competition. And so I asked teachers from our division, Limbang area to help me check all the writing. So after that, I explained to them... your writing will be marked by some English teachers so they were really happy and the really participate in the writing competition. So the results to me is very good, yes...."
\end{abstract}

(FGD171020)

Table 4: Teacher's Effort in their E-learning Implementation

\begin{tabular}{llll}
\hline Response in Survey Item & Construct & Frequency & Percent \\
\hline $\begin{array}{l}\text { I somewhat did not try to implement e- } \\
\text { learning as best I could during MCO. }\end{array}$ & Neutral Attitude & 1 & $2.0 \%$ \\
$\begin{array}{l}\text { I am unsure if I implemented e-learning as Neutral Attitude } \\
\text { best I could during MCO. }\end{array}$ & 9 & $18.0 \%$ \\
$\begin{array}{l}\text { I somewhat implemented e-learning as } \\
\text { best I could during MCO. }\end{array}$ & Positive Attitude & 28 & $56.0 \%$ \\
$\begin{array}{l}\text { I implemented e-learning as best I could } \\
\text { during MCO. }\end{array}$ & Positive Attitude & 12 & $24.0 \%$ \\
\begin{tabular}{l} 
Total (N=50) \\
\hline
\end{tabular} & 50 & $100.0 \%$ \\
\hline
\end{tabular}

Table 4.0 shows the findings for Attitude Item 4 which measures teachers' attitude based on their effort in implementing e-learning during the MCO. The results of this item's statistical analysis show that a majority of the respondents believe that they have implemented e-learning during the MCO to the best of their ability with $80 \%$ or 40 out of 50 of the respondents falling under the "Positive Attitude" category. They are divided amongst them with $24 \%$ or 12 out of 50 having no doubts at all that they have done their utmost in implementing e-learning and $56 \%$ or 28 out of 50 believing that they did their best but may be other factors could have played in helping them to do better. Meanwhile the rest of the respondents fell under the "Neutral Attitude" category.

When we triangulate these findings with the findings from the open-ended item and focus group discussion, we understand why there was uncertainty among the teachers whether they have done their best or not. Some teachers were held back due to logistical constraints with factor such as the MCO in play where movements were restricted. As mentioned in the previous section, one of the teachers in the focus group discussion did not have internet connection in the area where she lived, she had to travel to relay information and carryout e-learning for her students. 
Other issues may include the teacher's own confidence in their ability to use the platforms as they have never tried it before and is suddenly thrown into the deep end of e-learning during the pandemic. The teachers have shown signs of their own doubts in their ability for example:

“...Something like Quizziz, Kahoot...they like that. But I've done (a set) on Quizziz. I take the ones other teachers make and share the link. I don't know how to [laughs]..."

(FGD171020)

Table 5: Teacher's Belief in E-learning As an Alternative

\begin{tabular}{|c|c|c|c|}
\hline Response in Survey Item & Construct & Frequency & Percent \\
\hline $\begin{array}{l}\text { I do not believe that e-learning is a } \\
\text { great alternative during the times of } \\
\text { COVID- } 19 \text {. }\end{array}$ & Negative Attitude & 1 & $2.0 \%$ \\
\hline $\begin{array}{l}\text { I somewhat do not believe that e- } \\
\text { learning is a great alternative during } \\
\text { the times of COVID-19. }\end{array}$ & Neutral Attitude & 3 & $6.0 \%$ \\
\hline $\begin{array}{l}\text { I am unsure to believe that e-learning } \\
\text { is a great alternative during the times } \\
\text { of COVID-19. }\end{array}$ & Neutral Attitude & 8 & $16.0 \%$ \\
\hline $\begin{array}{l}\text { I somewhat believe that e-learning is a } \\
\text { great alternative during the times of } \\
\text { COVID-19. }\end{array}$ & Positive Attitude & 24 & $48.0 \%$ \\
\hline $\begin{array}{l}\text { I believe that e-learning is a great } \\
\text { alternative during the times of } \\
\text { COVID-19. }\end{array}$ & Positive Attitude & 14 & $28.0 \%$ \\
\hline Total $(\mathrm{N}=50)$ & & 50 & $100.0 \%$ \\
\hline
\end{tabular}

Table 5 shows the findings for Attitude Item 5 which measures teachers' attitude in the context of their belief in it as an alternative way to educate in times of a pandemic. From the results, it is shown that majority of the respondents had a "Positive Attitude" about e-learning being an alternative during times of COVID-19 with 38 out of 50 respondents falling into this category. This particular item measures the construct of attitude towards e-learning in the context of it being used as an alternative to traditional education to ensure that learning continues to happen in times of a pandemic. $28 \%$ or 14 out of 50 of the respondents were incredibly positive in their stance in which they agreed with the statement "I believe that e-learning is a great alternative during the times of COVID-19" and another $48 \%$ or 24 out of 50 of the respondents agreed that they "somewhat believe that e-learning is a great alternative during the times of COVID-19".

Another $22 \%$ or 11 respondents fell under the "Neutral Attitude" category and only $2 \%$ or 1 participant fell under the "Negative Attitude" category in which this individual "does not believe that e-learning is a great alternative during the times of COVID-19." From the focus group discussion, the theme that arose relating to this would be readiness. The teachers who were involved in the focus group discussion spoke on the readiness of teachers to implement e-learning. They mentioned that it came as a surprise and adjustments were difficult due to the drastic measures which Malaysia as a nation have had to take in order to curb the spread of the COVID-19 Virus.

"...Because this is a really what we call is unexpected pandemic, you know? And suddenly it is going to be a long school holiday like that. So the students reallyand the teachers unexpected this situation so when GC is not really implemented for example for schools in the rural area so it is impossible for them to simply log in and go through and try doing activities in the GC..." 


\section{Open Ended Responses}

The recurring theme from the open-ended item responses was readiness. These were concerning the readiness of Malaysian students to embark on an online learning program as well as infrastructural and economic readiness of the communities in Malaysia to undergo an education system which is siphoned through an online medium.

Many of the teachers who participated in the research maintain the opinion that e-learning was unable to be carried out effectively due to the existing conditions in Malaysia. This is in congruence with the statement by Malaysian UNESCO representative that e-learning has widened the socioeconomic gap and leaving the more economically handicapped students behind (Kamal, 2020). Students from lower socioeconomic background live in areas where there are no internet connection and network coverage making it close to impossible to have online classes in the regular sense of the term. The teachers also brought up the fact that the MCO was an unexpected move which threw the Malaysian education system into the deep end of the e-learning pool while our proficiency in conducting e-learning is still in its infancy stage with blended learning being a practice in school where it still heavily relied on face-to-face instruction and technology assisted learning (Wai \& Seng, 2015; Wong et al., 2016).

It is important to note however that most of the teachers have an optimistic attitude concerning the elearning approach. Noting that via a process of trial-and-error teachers and students alike have improved their e-learning sessions as it was a "sink-or-swim" situation. The teachers noted that with this experience, they are able to prepare beforehand and if an opportunity arises where an interaction with the students is possible, they will definitely allocate time to train and experiment with various elearning platforms to ensure a smoother and more effective e-learning session should another MCO were to happen. This finding resounds the findings of Mei and her colleagues where teachers although facing some challenges in implementing the e-learning tool are optimistic that with training it is well feasible within their context (Mei et al., 2017).

\section{Teacher's Level of Technological Literacy}

This construct measures technological literacy where the participants self-evaluate themselves to fit into 3 categories: low proficiency, average proficiency, and high proficiency. It concerns the level of digital proficiency possessed by the teachers and their confidence in executing technology-centered learning activities. The data relating to this are collected from the survey questionnaire and focus group discussion. There are 4 items which measured the construct of technological literacy of teachers from a quantitative standpoint in the survey. The data on these 4 items are as follows.

\section{Likert Scale Items}

Table 6.0 shows the findings from Tech Literacy Item 1 which measures the technological literacy of the teachers based on their familiarity and competence in handling various e-learning platforms. Majority of the respondents involved in the research fell under the "Low Proficiency" group since their confidence in conducting e-learning was limited to only 1-2 platforms.

Table 6: Technological Literacy of Teachers

\begin{tabular}{clll}
\hline Response in Survey Item & Construct & Frequency & Percent \\
\hline Uses 1-2 platforms & Low Proficiency & 30 & $60.0 \%$ \\
Uses 3-4 platforms & Average Proficiency & 11 & $22.0 \%$ \\
Uses >5 platforms & High Proficiency & 9 & $18.0 \%$ \\
Total $(\mathrm{N}=50)$ & & 50 & $100.0 \%$ \\
\hline
\end{tabular}

However, through insights brought by the participants in the focus group discussion it was found that the reason for the usage of limited platforms is due to the access in which the school community has. 
Not only that, but teachers must also cater to the technological literacy level of the parents as parents are not able to support the e-learning at home through a platform which they are not familiar with. An example of this can be seen from the excerpt:

"...So... Even when I posted the task sheet in the Google Classroom, none of them responded in that! [laughs] So maybe because they didn't know how to use, the parents didn't know how to use (Google Classroom) and... what more to say the students, right? So yeah, my problem is not with the students but with the parents. Because parents are the one that controls the phones and laptops, right?..."

(FGD171020)

Table 7: Teachers Practices in Incorporating Technology in the Classroom

\begin{tabular}{llll}
\hline Response in Survey Item & Construct & Frequency & Percent \\
\hline $\begin{array}{l}\text { I somewhat do not incorporate } \\
\text { technology in the classroom. }\end{array}$ & Low Proficiency & 7 & $14.0 \%$ \\
$\begin{array}{l}\text { I am unsure if I incorporate } \\
\text { technology in the classroom. }\end{array}$ & Low Proficiency & 20 & $40.0 \%$ \\
$\begin{array}{l}\text { I somewhat do incorporate } \\
\text { technology in the classroom. }\end{array}$ & Average Proficiency & 21 & $42.0 \%$ \\
$\begin{array}{l}\text { I do incorporate technology in the } \\
\text { classroom. }\end{array}$ & High Proficiency & 2 & $4.0 \%$ \\
Total (N=50) & 50 & $100.0 \%$ \\
\hline
\end{tabular}

Table 7.0 shows the findings for Tech Literacy Item 2 which measures the technological literacy level of the teachers based on their practices of incorporating technology in the classroom. The results show that a majority of the respondents falling in the "Average Proficiency" category as they agree with the statement "I somewhat do incorporate technology in the classroom". This is then followed by another large percentage of the group which agrees with the statement "I am unsure if I incorporate technology in the classroom" which makes up $40 \%$ of the total number of respondents.

The findings from the focus group discussion supports the findings from the survey as most of the teachers that participated in the focus group discussion do normally incorporate some level of technology in their classroom with the exception of some instances in the rural area where there are issues such as access to electricity. Other than that, the teachers do incorporate some level of technology into their classes so as to create a more holistic learning experience. This can be seen from the excerpt:

"...I am also very pleased to conduct this e-learning even until now even we already come to school as normal. E-learning is still in progress. They still like the response from teachers, as you mentioned just now. The very fast feedback, the emoji, the praises that they get from the teacher especially those who very committed with their homework, okay? That simple emoji will help them improve, uh I mean make them really encouraged to do more and more and ask for more exercise. ..."

(FGD171020)

Table 8: Teachers' Familiarity with Incorporating Technology in the Classroom

\begin{tabular}{lccc}
\hline \multicolumn{1}{c}{ Response in Survey Item } & Construct & Frequency & Percent \\
\hline $\begin{array}{l}\text { I am not used to incorporating } \\
\text { technology in class before MCO. }\end{array}$ & Low Proficiency & 4 & $8.0 \%$ \\
\hline
\end{tabular}



DOI: https://doi.org/10.47405/mjssh.v6i5.797

$\begin{array}{lccc}\begin{array}{l}\text { I am somewhat not used to } \\ \text { incorporating technology in the } \\ \text { classroom before MCO. }\end{array} & \text { Low Proficiency } & 12.0 \% \\ \begin{array}{l}\text { I am unsure if I am used to } \\ \text { incorporating technology in the } \\ \text { classroom before MCO. }\end{array} & \text { Average Proficiency } & 19 & 38.0 \% \\ \begin{array}{l}\text { I am somewhat used to incorporating } \\ \text { technology in the classroom before }\end{array} & \text { Average Proficiency } & 21 & 42.0 \% \\ \begin{array}{l}\text { MCO. } \\ \text { Total }(\mathrm{N}=50)\end{array} & 50 & 100.0 \%\end{array}$

Table 8.0 shows the findings for Tech Literacy Item 4 which measures the technological literacy of teachers based on their level of familiarity with the incorporation of technology in the classroom. According to the works of Wai \& Seng (2015) and Noh et al. (2019), this is a practice which makes up the essence of blended learning. For this particular item, the results show that majority of the respondents fall under the "Average Proficiency" category in which $80 \%$ or 40 out of 50 of the respondents agree with the statement "I am somewhat used to incorporating technology in the classroom before MCO" signifying an awareness of what the practice of incorporating technology in the classroom is and also a certain level of familiarity in practicing said practices while the others agreed with the statement "I am unsure if I am used to incorporating technology in the classroom before MCO" which signifies that there were some classroom activities which was carried out with the aid of a technological tool however the teacher is unsure whether it is considered as an incorporation of technology in the classroom.

The reason for the high percentage of respondents agreeing with the statement "I am unsure if I am used to incorporating technology in the classroom before MCO" is probably due to the use of authentic technology meaning a technological tool which was not developed for the classroom. For example, teachers who relayed classroom activities via Whatsapp found it difficult to think of what they doing as "e-learning". Due to Whatsapp primarily being a social media application it was difficult for them to shift the context into a teaching and learning experience. Such sentiment can be seen from the excerpt of the focus group discussion:

"...the parents could not provide the medium, the phones, the laptops for the kids to use so that we can actually all learn together, like sit there and learn at the same time. So I just use Whatsapp. Like, I screenshot the task sheet and or I take pictures (of the exercise) and give to the parents..."

(FGD171020)

Table 9: Teachers' Level of Difficulty in Implementing E-learning According to Their Technological Proficiency

\begin{tabular}{llll}
\hline \multicolumn{1}{c}{ Response in Survey Items } & Construct & Frequency & Percent \\
\hline $\begin{array}{l}\text { Most of the problems I face in } \\
\begin{array}{l}\text { implementing e-learning is not due to } \\
\text { my own lack of expertise in ICT. }\end{array}\end{array}$ & 13 & $26.0 \%$ \\
$\begin{array}{l}\text { Most of the problems I face in } \\
\text { implementing e-learning is somewhat } \\
\text { not due to my own lack of expertise in }\end{array}$ & High Proficiency & 5 & $10.0 \%$ \\
ICT. & & \\
\hline
\end{tabular}




\begin{tabular}{|c|c|c|c|}
\hline $\begin{array}{l}\text { I am unsure that most of the problems } \\
\text { I face in implementing e-learning is } \\
\text { due to my own lack of expertise in } \\
\text { ICT. }\end{array}$ & Average Proficiency & 8 & $16.0 \%$ \\
\hline $\begin{array}{l}\text { Most of the problems I face in } \\
\text { implementing e-learning is somewhat } \\
\text { due to my own lack of expertise in } \\
\text { ICT. }\end{array}$ & Average Proficiency & 21 & $42.0 \%$ \\
\hline $\begin{array}{l}\text { Most of the problems I face in } \\
\text { implementing e-learning is due to my } \\
\text { own lack of expertise in ICT. }\end{array}$ & Low Proficiency & 3 & $6.0 \%$ \\
\hline Total $(\mathrm{N}=50)$ & & 50 & $100.0 \%$ \\
\hline
\end{tabular}

Table 9.0 shows the findings for Tech Literacy Item 4 which measures the technological literacy of teachers based on the level of difficulties they feel that they have faced in the implementation of elearning during the MCO. The results show that most of the respondents in the research fell under the "Average Proficiency" category with a total of $42 \%$ or 21 out of 50 of the respondents agreeing with the statement "Most of the problems I face in implementing e-learning is somewhat due to my own lack of expertise in ICT". This signifies that the teachers feel that if they were better at using e-learning platforms they believe e-learning could run more effectively.

This is supported by the findings from the focus group discussion in which teachers mentioned the alienness of using Google Classroom with their students. It felt foreign to them and the act of logging into individual accounts to attend the "class" was an awkward experience which most students and to a certain extent-the teacher would like to do without. This is why they moved to more familiar applications and repurposed it for education as most teachers in the group have done with the social media application, Whatsapp. The excerpt below illustrates this situation:

$$
\begin{aligned}
& \text { "... I helped the students to log in everything and the I asked the parents. When I } \\
& \text { ask the parents to open, only one or two responded. Some of them didn't even read } \\
& \text { my message and some of them know nothing about it..." }
\end{aligned}
$$

(FGD171020)

\section{Limitations of the Study and Recommendations}

It is important however to reiterate the point made in the introduction that the findings of this research can only truly reflect the experience of implementing e-learning for the Limbang English teaching community and is not to be generalized into other contexts. For future researches, it is suggested that a larger sample size is taken from various states to provide a holistic view of the implementation of elearning in Malaysia. Another angle for further research can also be to investigate the relationship between peer, family and professional support with the student-content interaction i.e. the quality and efficacy of the e-learning initiative that is being undergone by the English teaching and learning community in Malaysia.

\section{Conclusion}

The main purpose of this study was to explore English teachers' attitudes, technological literacy, and challenges in implementing e-learning amidst the COVID-19 pandemic. Teachers were challenged in an unprecedented way to innovate learning. They are challenged to use a platform which in previous times have presented themselves as either an option or as a supplement from the organic interaction they had with their students to suddenly becoming the only means of communicating education and knowledge. Although seemingly to have been backed into a pit, what with practical issues such as lack of access to 
stable internet connection and only a threshold level of technological proficiency, teachers were resourceful and perseverant in delivering education to their students utilizing unlikely tools and devising creative activities on platforms such as Whatsapp.

In conclusion, through the context of the participants in this research, it is the researcher's belief that given enough support the education community in Malaysia would be able to thrive in e-learning. The researcher makes this claim due to the positive attitudes of the teachers who are creative, resourceful, and perseverant, their existing level of technological literacy and their willingness to learn and adapt to changes and their relentlessness in facing the challenges that come their way.

\section{References}

Borneo Post. Many Dilapidated Schools In Sarawak. December 14th, 2019. Retrieved from: https://www.theborneopost.com/2019/12/14/many-dilapidated-schools-in-sarawak-yet-to-berepaired/

Charmonman, S. (2006). Level E-learning in ASEAN and Thailand. Paper presented at the B3-Elearning Euro Southeast Asia 2006, Singapore, Thailand.

Department of Statistics Malaysia. (2019). Household Income and Basic Amenities Survey Report by State and Administrative District Sarawak. Putrajaya: Department of Statistics Malayia.

Forero, D. A., Lopez-Leon, S., González-Giraldo, Y. \& Bagos, P. G. (2019). Ten simple rules for carrying out and writing meta-analyses. PLOS Computational Biology 15(5): 1-7. doi:10.1371/journal.pcbi.1006922

Garrison, D. R., Anderson, T., \& Archer, W. (2000). Critical inquiry in a text-based environment: Computer conferencing in higher education model. The Internet and Higher Education, 2(2-3), 87105.

Goi, C.H. \& Ng, P.Y. 2009. E-learning in Malaysia: Success Factors in Implementing E-learning Program. International Journal of Teaching and Learning in Higher Education 20 (2), 237-246.

Harashim, L. (2012). Learning theory and online technologies. New York: Routledge/Taylor \& Francis.

Heyvaert, M., Hannes, K., Onghena, P. (2017). Using mixed methods research synthesis for literature reviews. Thousand Oaks, CA: Sage..

Kamal, A. (2020). Digital Learning in the New Normal. Youtube Live: Eduweb TV. Webinar. 15 June.

Krejcie, R.V., \& Morgan, D.W. (1970). Determining Sample Size for Research Activities. Educational and Psychological Measurement, 30, 607-610

Malaysian Ministry of Education. (2020). Surat Siaran Kementerian Pendidikan Malaysia Bilangan 3 Tahun 2020: Garis Panduan Pelaksanaan Pengajaram dan Pembelajaran (PdP) Semasa Perintah Kawalan Pergerakan Disebabkan Penularan Jangkitan Covid-19. Putrajaya.

Mei, L.C., Wong, S.L., Ayub, A.F., Mahmud, R. (2017). Teacher's Perceptions of E-learning in Malaysian Secondary Schools. MOJET: Malaysian Online Journal of Educational Technology 5(2). 20-33

Mohd Zulhilmi Che Had \& Radzuwan Ab Rashid. (2019). A Review of Digital Skills of Malaysian English Language Teachers. International Journal of Emerging Technologies in Learning Vol 14(2). 139-145. https://doi.org/10.3991/ijet.v14i02.8732

Noh, N., Abdullah, N., Teck, W., \& Hamzah, M. (2019). Cultivating Blended Learning in Teaching and Learning: Teachers' Intrinsic and Extrinsic Readiness in Malaysia. International Journal of Academic Research in Business and Social Sciences, 8(2), 2.

Picciano, AG. (2017). Theories and Frameworks for Online Education: Seeking an Integrated Model. Online Learning, 21(3), 166-190, doi: 10.24059/olj.v21i3.1225

Price, P., Jhangiani, R., Chiang, I., Leighton, D., \& Cuttler, C. (2017). Research Methods in Psychology - 3rd American Edition. Washington: PressBooksPublications.

Schwarz, N. (2015). Metacognition. 10.1037/14341-006.

Siemens, G. (2004). Connectivism: A learning theory for the digital age. Paper retrieved from: http://www.elearnspace.org/Articles/connectivism.html

UNESCO. (2020). Education and Literacy: Malaysia. Retrieved from: http://uis.unesco.org/en/country/my?theme=education-and-literacy

UNICEF. (2020). Partial, uneven, and uncertain: Families on the Edge report chart recovery among 
DOI: https://doi.org/10.47405/mjssh.v6i5.797

low income families post-MCO. Retrieved from: https://www.unicef.org/malaysia/pressreleases/partial-uneven-and-uncertain-families-edge-report-chart-recovery-among-low-income. [10 OCTOBER 2020]

UNICEF. (2020). Keeping the world's children learning through COVID-19. Retrieved from: https://www.unicef.org/coronavirus/keeping-worlds-children-learning-through-COVID-19 April 2020]

Wai, C.C. \& Seng, E.L.K. (2015). Measuring the effectiveness of blended learning environment: A case study in Malaysia. Education Information Technology 20, 429-443. https://doi.org/10.1007/s10639013-9293-5

Wisdom, J. \& Creswell, J.W. (2013). Mixed Methods: Integrating Quantitative Data Collection and Analysis While Studying Patient-Centred Medical Home Models. AHRQ Patient Centered Medical Home Resource Centre. Retrieved from: https://pcmh.ahrq.gov/page/mixed-methods-integratingquantitative-and-qualitative-data-collection-and-analysis-while

Wong, K.T, Hamzah, M.S.G., Goh, P.S.C. \& Yeop, M.A.B. (2016). Blended E-learning Acceptance as Smart Pedagogical Tools: An Initial Study in Malaysia. Turkish Online Journal of Educational Technology 15(4), 25-31.

Yeoh, A. (2020). The Star: MCO: Telcos to offer free 1GB data daily from April 1, here's what you should know. Retrieved from: https://www.thestar.com.my/tech/tech-news/2020/03/27/mco-telcosto-offer-free-1gb-data-daily-from-april-1-here039s-what-you-should-know [27 March 2020] 